\title{
The Hard but Holly Life of the Eco-Warrior of Holden
}

\author{
Junhong Tang ${ }^{1 *}$, Wei Zhang ${ }^{2}$ \\ ${ }^{1}$ The Foreign Language Department of Baoding University, Baoding, China \\ ${ }^{2}$ Educational Administration of Jibei Baoding Electric Power Vocational and Technology College, Baoding, \\ China \\ Email: *jessytang99@163.com
}

Received July $13^{\text {th }}$, 2013; revised August $7^{\text {th }}$, 2013; accepted September $27^{\text {th }}, 2013$

Copyright (c) 2013 Junhong Tang, Wei Zhang. This is an open access article distributed under the Creative Commons Attribution License, which permits unrestricted use, distribution, and reproduction in any medium, provided the original work is properly cited.

\begin{abstract}
It is easy for us to make a conclusion that Holden loves nature, admires nature and lives in harmony with nature. Meanwhile, he prefers simple life style. Unfortunately, he is always misunderstood, excluded and even persecuted by the people around him and there are few people who share his ambitions and outlook on life. Holden's life situation is similiar to the modern environmentalists, so the aim of the paper is to remind people that each citizen is supposed to fully understand and support the environmentalists' holly mission.
\end{abstract}

Keywords: Eco-Warrior; Holden; Environmentalists

\section{Introduction}

With the gradual deterioration of the environment and the development of eco-criticism, more and more literary works are reread and reanalyzed in terms of eco-criticism. The Cather in the Rye is analyzed from the perspective of eco-criticism in this paper and the paper intends to show Holden's ecological responsibility, ecological wholeness and his simple life view and reveal Holden's hard but holly life.

The development of science and technology offers people more chances and possibilities to enjoy higher level of life while the evil desire of human beings also has been inflating (Lu, 2006). Some people explore the resources without little regard of the earth's endurance and pollute the environment with the lure of maximum profit. So the modern ecology is in a state of imbalance. Because this kind of persons who destroy the ecological environment intentionally or unintentionally, directly or indirectly are in the majority, whereas the environmentalists are in the absolute minority, the minorities will face many difficulties and obstacles. Just as Holden Caulfield in The Catcher in the Rye, he admires the simple life, cares about the nature, loves the nature and only wants to be a catcher in the rye, but, unfortunately, he is always misunderstood, hurt and excluded, so his life is hard but holly.

\section{Holden's Ideal Work and Living Place}

One person's ideal work and his or her ideal living place can reveal one person's personalities and his or her likes and dislikes (Fromm, 1987). In The Catcher in the Rye, Holden's ideal work - to be a catcher in the rye and his ideal living place- the west show that Holden is a real eco-warrior.

\section{Holden's Ideal Work}

“Anyway, I keep picturing all these little kids playing some

\footnotetext{
"Corresponding author.
}

game in this big field of rye and all. Thousands of little kids, and nobody's around-nobody big, I mean-except me. And I'm standing on the edge of some crazy cliff. What I have to do, I have to catch everybody if they start to go over the cliff-I mean if they're running and they don't look where they're going I have to come out from somewhere and catch them. That's all I'd do all day. I'd just be the catcher in the rye and all." (Salinger, 1991) The title of the novel is The Catcher in the Rye and Holden's ideal work is to be a catcher in the rye, so the catcher in the rye is one of the most important and significant symbols in the novel. In the symbol, there is the enjoyable Eden for the children - the rye, which is the holly area that Holden would like to watch all the day; there is the cliff form which the children may fall off, and which is also the watershed between the beautiful nature and the evil society (Tang, 2013); there is also the eco-warrior-Holden Caulfield who is ready to catch the child who is going to fall off the cliff.

On the one hand, we can regard the children in the rye as the children in terms of physiological age. The children are close to the nature and they have the purest personalities: honest, warm-hearted, affectionate and pure. Thoreau once said in his Walden that the children can find the life law easier than the adults. On the other hand, the playing children in the rye can be considered the children of nature - the human beings. "...I mean if they're running and they don't look where they're going..." This is the vivid description of the modern people. In modern society, most of the modern people-the nature's children have been falling off the cliff and they are exploring the resources without little regard of the earth's endurance and polluting the environment with the lure of maximum profit. The eco-warrior Holden appears at the critical time and he is willing to act as the angel "I have to come out from somewhere and catch them.” to protect the children and make the children play in the rye enjoyably.

At present, we are faced with the rapid exhaustion of the earth's natural resources, the severe deficiency of water and the 
pollution of the environment. So the eco-warrior like Holden is urgently needed and each person is expected to understand, support and even become an eco-warrior.

\section{Holden's Ideal Living Place}

"We'll stay in these cabin camps... we could live somewhere with a brook... I could chop all our own wood in the wintertime and all. Honest to God, we could have a terrific time!” (Salinger, 1991) “... I'd start hitchhiking my way out West... I'd build me a little cabin somewhere with the dough I made and live there for the rest of my life. I'd build it right near the woods... and we'd get married. She'd come and live in my cabin with me.” (Salinger, 1991) It is obvious that Holden's ideal living place is a cabin in a wood. As a matter of fact, Holden lives in the building of New York, but he is not happy, enjoyable and satisfied with it, "I hate living in New York" (Salinger, 1991) and he prefers to live in a cabin in the woods. The living place of one person is the most important thing that can reveal what the person think about and what the person cherish most.

Holden's ideal living place-a cabin in the woods is a good proof for Holden's ecological life style. He loves the nature, admires the nature and can live in harmony with the nature. While Holden's ecological life style is on the contrary with most modern people's life style. Most modern people would like to live in big cities and enjoy the quick transportation and the fast life pace. By relying on the advanced science and technology, they live in a matter of high energy. For example, they like cars very much and they will drive their cars when they want to go somewhere though sometimes it is ok by bike or by bus. Moreover, some people think it is an honorable thing to eat some expensive dishes in the restaurant. In such a way, the minority of the environmentalists who advocate simple life like Holden will stand on the opposite with some modern people, so they will be always misunderstood, excluded even hurt.

\section{Things Holden Cares About}

With the rapid development of the economy and the fast improvement of the production, people's living standard has been improving day by day and the desires of the people has been becoming more and more, bigger and bigger. While Holden's life style is absolutely different from the life style of most modern people, he cares about the ducks in the lake and he prefers simple life style.

\section{Holden's View of Simple Life Style}

“...if they get a brand-new car already they start thinking about trading it in for one that even newer. I don't even like old cars. I mean they don't even interest me, I'd rather have a goddam horse. A horse is at least human..." (Salinger, 1991) “Lawyers are all right, I guess-but it doesn't appeal to me, ...if you're a lawyer. All you do is make a lot of dough and play golf and play bridge and buy cars and drink Martinis and look like a hot-shot.” (Salinger, 1991) Clearly, Holden does not pursue the material enjoyment, does not indulge in the money temptation and good cars can not attract him. What Holden like is just simple life style.

Money, wealth and luxurious life are not the honorable symbol for Holden, but the disgraceful token of over-consumption and over-waste. Holden has his own expensive coat but he does not take it but lend it to others “...how about lending me your hound's-tooth jacket?” (Salinger, 1991); Holden has his own perfect typewriter, but he does not use it but lend it to others "...I went down the hall and woke up Frederick Woodruff, this guy I'd lent my typewriter to.” (Salinger, 1991); and Holden also has the good-quality and expensive suitcase, but he never intends to show off. "It depressed holy hell out of me, and I kept wanting to throw mine out or something...I finally put my suitcase under my bed...so that old Slagle wouldn't get a goddam inferiority complex about it.” (Salinger, 1991). On the contrary, Holden like the hat which only cost him a buck best. Holden's simple life style view is obvious and clear. At the same time, the ecological responsibilities also exist in his deep heart.

\section{Holden's Care about the Ducks}

The ducks in the central park always appear on Holden's mind. It is four times that the ducks are mentioned in The Catcher in the Rye (Tang, 2006). Holden pays much attention to where the ducks will go when winter comes which shows Holden's view of ecological wholeness.

The ducks appears at the first time when Holden talks with his history teacher Spenser. "and if it was, where did the ducks go.” (Salinger, 1991) On the way to Edmund, Holden asks the taxi-driver about the ducks at the second time "do you happen to know where they go, the ducks, when it gets all frozen over?” (Salinger, 1991) On the way to Ernie, Holden asked another taxi-driver the same question "Do you happen to know where they go in the winter-time, by any chance?" "Where who goes?” (Salinger, 1991) this is the response of the taxi-driver Horwitz to Holden's question about ducks. Just "where who goes" conveys Horwitz completely ignores the existence of the ducks. "How the hell should I know a stupid thing like that" (Salinger, 1991) illustrates the taxi-driver does not concern about where the ducks will go in the winter and exposes his "human centered principle". Most modern people take for granted that human beings are the lord of the nature. They think all the things including the live and the dead, animals, plants and minerals belong to them and they can consume them unscrupulously. The "human centered principle" leads to this result that animals like the ducks are at the edge of being loved.

The reason that Holden cares much about the ducks is that he thinks human beings are not the lord of the earth and all things are equal on the earth and all the animals, plants and human beings are brothers and sisters. All of them are the children of the nature and they should accept the same favor.

Under the lowest mood, Holden mentions the ducks at the fourth time. "But I didn't see any ducks around... I damn near fell in once, in fact-but I didn't see a single duck.” (Salinger, 1991) In despair, Holden intends to find the ducks to comfort himself a little, but he is wrong-the ducks had flew away from him. He thought he was a friend of the ducks, the nature, while he is not able to create a friendly relationship between him, one of human beings, and the ducks, one part of the nature. Meanwhile, Holden's relationship with the human beings is also in tense.

\section{Holden Lives in Disharmony with the People and the Things around Him}

"One of the biggest reasons I left Elkton Hills was because I was surrounded by phonies...For instance, they had this head- 
master, Mr. Haas, that was the phoniest bastard I ever met in my life.” (Salinger, 1991) Holden not only is not satisfied with the headmaster's ingratiating behaviors but also dislike his roommate, Ward Stradlater. Because Stradlater pay more attention to his outer appearance and he makes a lot of girlfriends. A physical altercation happened between Holden and his roommate, Stratlater only because Stratlater forgot to ask a question on behalf of Holden. "the next thing I knew I was on the goddam floor again... my nose was bleeding all over the place." (Salinger, 1991) Because of the different view of life, Holden can not live in harmonious with his roommate who pays much attention to his outer appearance.

"The trouble was, though, my address book only has about three people in it, Jane, and this man, Mr. Antolini....and my father's office number.” (Salinger, 1991) In the novel, Holden called Jane many times but there is no answer all the time. Finally, he calls on Mr. Antolini who he thinks is the best teacher he ever met. "He was about the best teacher I ever had, Mr. Antolini.” (Salinger, 1991) Because of Antolini's weird behavior Holden has to escape from Antolini's house. While when Holden tells his sister Phoebe that he only wants to be a catcher in the rye, Phoebe says nothing but "Daddy's going to kill you."

All of the things happened around Holden proved that there is no person who shares Holden's ambitions and outlook on life. He can not get comfort form his parents and he is not able to live happily with his roommates. Holden always slip into a state of loneliness and helplessness. At last, Holden gets run-down and has to come to a mental sanatorium.

\section{Conclusion}

The hard life of the eco-warrior of Holden is the same as the tragedy of the environmentalists. Although more and more organizations of protecting the environment have been con- structed and more and more eco-warriors, eco-radicals and eco-terrorists have been appearing, they are still in the minority compared with the majority of the people who explore the nature for their maximum profit without consideration of the nature's endurance (Wang, 2005). So the eco-warriors are always misunderstood, excluded and even persecuted. To some degree, they do not fight for protecting the nature, but fight for people's endless evil desire, for people's immoral plunder and for people's iresponsible short-sighted behaviors. Under this situation, each citizen is required to devote to protecting the nature and is also expected to fully understand and support the ecowarrior's holly mission of protecting the nature.

\section{Acknowledgements}

The paper is under the project of a Study on College English Ecological Teaching (133111). All the project members made their contributions to the paper. I also thank all my friends and classmates who live in different cities, which made my paper more persuasive.

\section{REFERENCES}

Fromm, E. (1987). The art of loving. Beijing: The Commercial Press. Lu, S. Y. (2006). The room of ecological criticism. Shanghai: East China Normal University Press.

Salinger, J. D. (1991). The catcher in the rye. Boston: Little, Brown and Company Limited.

Tang, J. H. (2013). Distorted mentatlity-thematic analysis of The Catcher in the Rye by Salinger's employment of symbolism. Baoding: North China Electric Power University.

Tang, J. H. (2006). The red and green in Holden's Life. Mang Zhong, 6, 58-59.

Wang, N. (2005). Eco-literature of Europe and America. Beijing: Peking University Press. 